\title{
INNOVATION, PROCESS CAPITAL AND FINANCIAL PERFORMANCE: MEDIATING ROLE OF MARKETING PERFORMANCE (EVIDENCE FROM MANUFACTURING INDUSTRY IN INDONESIA)
}

\author{
Bambang Tjahjadi*, Hanna Miriam Shanty, Noorlailie Soewarno \\ Faculty of Economics and Business, Universitas Airlangga, Indonesia \\ *bambang.tjahjadi@feb.unair.ac.id, hannamshanty@gmail.com, noorlailie-s@feb.unair.ac.id \\ Article History: Received on $02^{\text {nd }}$ February Revised on $30^{\text {th }}$ April, Published on $20^{\text {th }}$ July 2019
}

\begin{abstract}
Purpose of the Study: This paper aims to investigate the mediating role of marketing performance on innovationfinancial performance relationship as well as on process capital-financial performance relationship using the publicly listed manufacturing firms on the Indonesia Stock Exchange (IDX).

Methodology: This is a quantitative research employing marketing performance as the mediation variable. A mediation research model is constructed to test the hypotheses of this research using the Partial Least Squares Structural Equation Modeling. A new data set is prepared which involves the publicly listed manufacturing companies on the IDX covering a period of thirteen years from 2005 to 2017.

Main Findings: The results of this research provide the following empirical evidence. Firstly, marketing performance partially mediates the relationship between innovation and financial performance. Secondly, marketing performance fully mediates the relationship between process capital and financial performance.
\end{abstract}

Conclusion: This study provides a better understanding of managers regarding the mechanism of how innovation affects financial performance via marketing performance as well as on the mechanism of how to process capital affects financial performance via marketing performance.

Application/Implication: This study implies that managers need to continuously innovate, improve manufacturing processes, and enhance marketing management to achieve better financial performance.

Keywords: Financial Performance, Marketing Performance, Innovation, Process Capital, Manufacturing Industry, Partial Least Squares Structural Equation Model

\section{INTRODUCTION}

Financial performance, specifically profitability performance, is the most important measure for profit-oriented firms. A firm has to compete with other firms in the market to gain a competitive advantage and good financial performance. A study of Jansson (2018) on the financial resilience of six of the largest Swedish companies revealed that a profitable core operation is crucial for achieving strong financial resilience. Further analysis of the study demonstrated that owners with a long-term orientation, who retain a part of the profit for future challenging times, are also important.

The manufacturing sector plays an important role in the Indonesian economy. Recently, it faces two important challenges. Firstly, the new overseas orders continue to decline. Secondly, the input costs rise due to the strength of the US dollar. This suggests that innovation and process capital are the two crucial determinants for market performance and profitability performance of the manufacturing companies in Indonesia.

In the era of knowledge economy, innovation is considered as the most critical determinant of financial performance because innovation is the source of competitiveness as well as growth. Slater and Olson (2001) stated that innovation is a strategy directed at the process of discovery, development, and implementation of new ideas related to the development of processes, technologies, and products. Kalkan et al. (2014) argued that innovation is the application of new ideas that create value. Process capital is another determinant of profitability performance. Different from other studies that focus on how companies use human capital in processes, this study focuses on the cost of goods sold as a result of the manufacturing process management. A firm with an efficient manufacturing process will have an efficient cost profile and will satisfy the customers. Chen et al. (2004) argued that in order to improve the relationship with customers, firms must reduce operating cycle time and develop high quality internal processes.

There are inconsistencies in the previous studies (Hariyati \& Tjahjadi, 2018; Rajapathirana \& Hui, 2018; Darroch, 2005; Gunday et al., 2011) and this research gap motivates us to conduct further research on the subject matter. This study introduces a variable that theoretically mediates the effect of innovation on financial performance as well as the effect of 
process capital on financial performance. This study employs marketing performance as a mediating variable for the following reasons. Firstly, marketing performance is a measure of firms' success in terms of product, price, place, and promotion strategies. In order to improve marketing performance, a firm has to introduce new products as a result of innovation. When marketing performance improves, sales will also increase. Fagerberg et al. (2004) emphasize that new products generally have a positive effect on sales. Secondly, an excellent process decreases manufacturing costs and improves marketing performance because it enables managers to give competitive prices to customers.

A new data set is prepared which involves the publicly listed manufacturing firms on the Indonesia Stock Exchange (IDX) during the period from 2005 to 2017. Samples were chosen using purposive sampling and resulted in 173 observations. This study has the following results. Firstly, it was found that marketing performance partially mediates the relationship between innovation and financial performance. This suggests that a firm needs to innovate continuously in the manufacturing of new products and processes to enhance marketing performance. Furthermore, good marketing performance leads to better profitability performance. Secondly, marketing performance mediates the relationship between process capital and financial performance. The decreasing manufacturing process costs enable managers to improve marketing performance, and marketing performance will further increase financial performance.

This research contributes to the literature on innovation management, manufacturing process management, marketing management, and finance, in terms of providing empirical evidence on the publicly listed manufacturing firms' research settings. The study results have practical implications for managers of manufacturing firms in Indonesia. It suggests that managers should continuously innovate in both products and processes to improve marketing and financial performance. It also suggests that managers should reduce manufacturing costs inefficiencies to drive better marketing and financial performance.

The rest of the paper is structured as follows. Section 2 presents the literature review and hypotheses development. Section 3 discusses the data and research method. Section 4 presents results and analysis. Section 5 describes the discussions. Section 6 concludes the study with the limitations and opportunities for future research.

\section{LITERATURE REVIEW AND HYPOTHESES DEVELOPMENT}

\section{Innovation}

Innovation is one of the driving forces for sustainable long-term economic growth (Shukla, 2017). Creative and innovative organization needs demand skilled workers for creating, acquiring, and transferring knowledge and for modifying behaviors to reflect new knowledge and insights (Rashid Al-Thehli \& Ahamat, 2019). Innovation refers to the process of discovery, development, and implementation of new ideas related to the development of processes, technologies, and products (Slater \& Olson, 2001). As the source of competitiveness and growth, innovation plays a crucial role in creating value in the era of knowledge economy. Knowledge is increasingly seen as a primary business asset and the basis for individual and organizational success (Yaakub \& Othman, 2014). A study by Hariyati and Tjahjadi (2018) proved that innovation strategy positively affects the financial performance of manufacturing companies in East Java. Studies by different scholars (Wang \& Chang, 2005; Ferrari \& La Rocca, 2010; Atalay et al., 2013; Bigliardi, 2013; Ezzi \& Jarboui, 2016; Rajapathirana \& Hui, 2018) provided a harmonious outcome in which innovation has a positive impact on financial performance. However, other studies conducted by Darroch (2005) and Gunday et al. (2011) showed that innovation has no effect on financial performance. This research gap justifies the importance of further studies.

\section{Process Capital}

A firm with an efficient manufacturing process will have an efficient cost profile and will satisfy the customers. Chen et al. (2004) argued that firms must reduce operating cycle time and develop high-quality internal processes to improve their relationship with customers. A study by Wang and Chang (2005) provides empirical evidence that process capital has a positive effect on performance. However, another study by Cheng et al. (2010) showed that process capital negatively affects performance. This research gap also justifies for further investigation.

\section{Marketing Performance}

Customer is the central issue in achieving marketing performance. An easy and good means to influence the customers is through social media marketing, although some customers do not feel secure through social media (Khan et al., 2017). Product, price, place, and promotion strategies determine the success of marketing performance. As a result of innovation, new products are crucial in improving marketing performance, which eventually results in the increase of 
financial performance. As stated by Fagerberg et al. (2004), new products generally have a positive impact on marketing performance. Process capital or an efficient manufacturing process decreases the cost of goods sold and enables managers to enhance marketing performance and financial performance by giving competitive prices to customers.

\section{Financial Performance}

Financial performance, especially profitability performance, is the most important measure to assess the health of a company. Financial performance is also used for predicting future financial position and operating results and cash flow in achieving the company's objectives (Wulan Sari, 2019). Gartenberg et al. (2019) stated that firms exhibiting both high purpose and clarity have systematically higher future accounting and stock market performance.

Based on the literature review, the hypotheses of the study are developed. This study employs seven hypotheses as per the following.

\section{Innovation and Financial Performance}

Each firm needs to produce innovations in an increasingly competitive business environment. A firm must be creative in developing products on the pressures of market demand or production technology improvements. Stagnant products tend to decrease consumers' desire to buy. When they are not satisfied, customers will always look for alternative products that conform to their expectations. The main purpose of the innovation process is to provide and deliver better customer value.

Innovation is the introduction of new products or processes and is a new combination of characteristics that align with potential customers' preferences. Innovation is defined as the application of new ideas that create value (Kalkan et al., 2014). Innovation must alter the characteristics of current products in such a way that the willingness of potential customers increases. Innovation is a difficult process and requires a boost in technological advancement, changing customer needs, and shortening product life cycles in increasing global competition.

Product innovation is an effort to meet customers' expectations. Customers get more benefit because such innovations can fulfill their needs. Product innovations also have an impact on performance due to the absence of competitors. The increasing performance resulted from new products provides benefits in terms of sales growth and profit improvement. The ability to innovate increases survival probability for all firms and across industry sectors (Cefis \& Ciccarelli, 2005; Cefis \& Marsili, 2004).

Studies by Padgett (2012), Aguilera-Caracuel and Ortiz-de-Mandojana (2013), and Bigliardi (2013) provide empirical evidence that innovation has a positive and significant impact on financial performance. The better the innovations created by firms, the better is the financial performance. Based on the previous justification, the first hypothesis is proposed as follows:

H1: Innovation is associated with financial performance

\section{Process Capital and Financial Performance}

Process capital contributes to improved productivity and cost reduction through more efficient use of inputs and allowing for larger production scales. Process costs reductions will certainly have a positive impact on improving financial performance. Effective and efficient processes are the goals of every company (Wang \& Chang, 2005). Process capital refers to the creation of quality products by optimizing the use of all resources. When a firm can provide benefits, then customers will be satisfied. Furthermore, they will continuously support the firm. A more efficient and effective process improves financial performance (Freeman, 1984). A study conducted by Wang \& Chang (2005) provides empirical evidence that intellectual capital has a positive and significant effect on financial performance. Chiu et al. (2017) also proved that process capital has a positive significant effect on firms' performance in Taiwanese biotechnology and pharmaceutical industry. The more efficient the process, the lower the cost of goods sold, and the higher the gross profit. This argument justifies the development of the following second hypothesis:

H2: Process capital is associated with financial performance

\section{Innovation and Marketing Performance}

Innovation plays a critical role in an increasingly fierce competition in the business world. Innovation refers to new ideas that focus on developing, producing, and marketing new products in order to build sustainable competitive advantage. Competitive advantage can be achieved if a firm is able to provide more value to customers compared to its competitors (Narver \& Slater, 1990). 
The number of new products generated from innovation will have an impact on increased sales and increased market share. The more creative the innovations created by firms, the fewer competitors the firms will face. Because of the perfect innovation, firms can determine the premium price of new products. High market share and premium price will certainly influence profit improvement.

Innovation relies on effective resource management (Kianto et al., 2017). Management must explore the knowledge possessed by employees. Developing different new ideas and putting them into marketing activities will improve marketing performance. The continuing creative process within firms will ensure firms survival and sustainable growth. Continuous competitive advantage can be achieved by continuously adapting both internal and external environments. Innovations are needed in marketing strategies, both during the formulation phase and execution phase. Innovative marketing activities will drive marketing performance. A study conducted by Al-Zyadaat et al. (2012) provides empirical evidence that innovation affects marketing performance. Lagat and Frankwick (2017) also suggest that there are direct effects of marketing research and marketing management on market performance, while there are also moderated effects of product development and pricing on market performance. The better the innovations, the higher the marketing performance that will be achieved by firms. Based on the previous arguments, the following third hypothesis is proposed:

H3: Innovation is associated with marketing performance

\section{Process Capital and Marketing Performance}

Efficient business processes will drive revenue improvements and cost reductions. Firms will improve their relationship with customers through shortening the cycle time of operations and developing high-quality internal processes. This will affect marketing performance as a whole. A study by Wang and Chang (2005) provides empirical evidence that intellectual capital has a positive effect on marketing performance. Firms that operate efficiently and effectively will be preferred by consumers because of better services. A study by Prajogo et al. (2016) in 232 Australian manufacturing firms demonstrated that inbound supply performance and lean production processes affect competitive performance. Based on the arguments, the following fourth hypothesis is developed:

H4: Process capital is associated with marketing performance

\section{Marketing Performance and Financial Performance}

Marketing performance is a critical part of the overall performance. Marketing performance is also regarded as the organization's ability to transform itself in the face of environmental challenges to its long-term survival (Keats \& Hitt, 1998). Marketing performance is a measure of achievement in marketing activities. A study by Smith and Chang (2010) in Taiwan showed the important role of good customer service on loyalty and performance. Good marketing performance is reflected by high sales value and increasing sales volume that affects firms' profits. Feng et al. (2015) reported that marketing departments could power and predict the future financial performance of firms. Lagat and Frankwick (2017) showed that there is a direct effect of marketing management on financial performance. Shiet al. (2018) revealed that marketing performance has an effect on financial performance. A study Liu et al. (2018) showed that higher product market competition is associated with lower firm performance. This argument justifies the following fifth hypothesis:

H5: Marketing performance is associated with financial performance

\section{Marketing Performance mediates Innovation-Financial Performance Relationship}

Inconclusive results of previous studies regarding the effect of innovation on financial performance indicate the existence of other variables that might mediate the relationship (Gunday et al., 2011; Padgett 2012; Aguilera-Caracuel \& Ortiz-deMandojana 2013; Bigliardi 2013; Tuan et al., 2013). The previous discussion provides theoretical and empirical support that innovation is associated with marketing performance and marketing performance is associated with financial performance. Chaston and Scott (2012) stated that innovation enables management to solve marketing problems, to fulfill customer expectations, to better commercialize products and to lead to higher market returns.

Gunday et al. (2011) argued that firms with product innovations do not experience good financial performance because those new products must be followed by good development and implementation of marketing activities. Mahmoud et al. (2016) showed that market orientation helps the firm in adapting to market needs and in turn affects banks' business performance. This indicates that marketing performance has an important role in mediating the relationship between innovation and financial performance. This argument justifies the development of the following sixth hypothesis:

H6: Marketing performance mediates the relationship between innovation and financial performance 


\section{Marketing Performance mediates Process Capital-Financial Performance Relationship}

Inconclusive results of previous studies by both Wang and Chang (2005) regarding the effect of intellectual capital including process capital on financial performance also indicate the existence of other variables that might mediate the relationship. The previous discussion also provides theoretical and empirical supports that process capital affects marketing performance and marketing performance affects financial performance. However, firms with good process capital do not always experience good financial performance if the firms only focus on operation processes. Kaplan and Norton (2001) argue that human capital competencies must be excellent in order to support internal business processes, namely operation management processes, customer management processes, and innovation processes as well as social and regulatory processes. Schramm-Klein and Morschett (2006) stated that logistic quality and sales performance affect financial performance. Ernst et al. (2010) also stated that a good customer relationship affects new product performance, and then it will affect future performance. Cheng et al. (2010) showed that efficient operation processes effect on firms' performance via good customer relationship in the American healthcare industry. Yu et al. (2013) argued that operations capability fully mediates the relationship between marketing capability and financial performance. Therefore, the better the process capital along internal business processes, including marketing activities, the better the financial performance. Those arguments lead to the formulation of the seventh hypothesis, as follows:

H7: Marketing performance mediates the relationship between innovation and financial performance

Based on the previous discussions, Figure 1 presents the research framework.

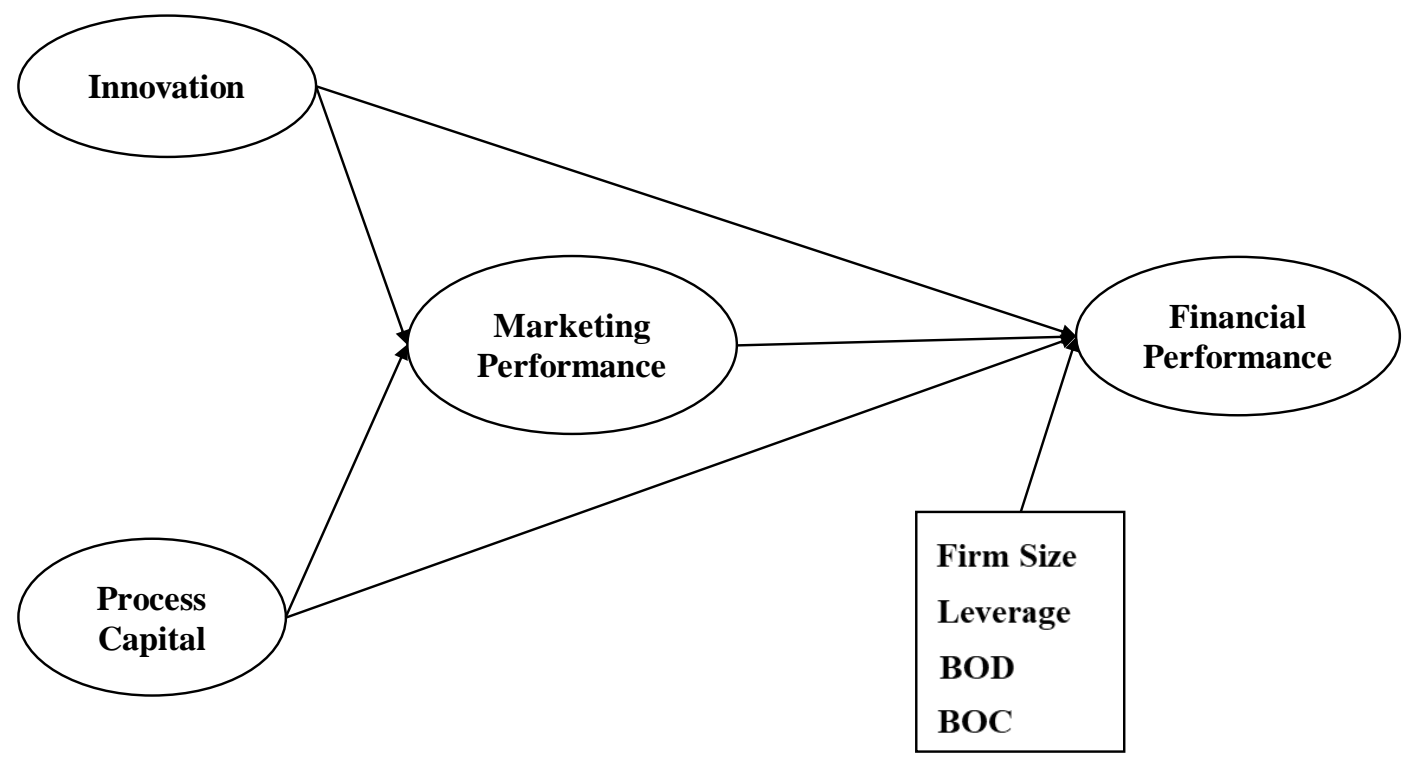

Figure 1. Research Framework

Figure 1 shows the research framework for this study, which investigates the issues of whether (1) innovation is associated with financial performance; (2) process capital is associated with financial performance; (3) innovation is associated with marketing performance; (4) process capital is associated with marketing performance; (5) marketing performance is associated with financial performance; (6) marketing performance mediates the relationship between innovation and financial performance; and (7) marketing performance mediates the relationship between innovation and financial performance. An application of WARP PLS version 5.0 was used to test the hypotheses.

\section{METHODOLOGY}

\section{Sample Selection}

We derive our sample from the Indonesia Stock Exchange (IDX) website in the form of financial statements of publicly listed manufacturing firms for the period of thirteen years from 2015 to 2017. Manufacturing firms are selected because they have relatively more complex business processes, heavily rely on innovations and process capital to maximize profit. The purposive sampling method is employed using the following criteria. First, the firm must publish complete financial statements as of December 31 to show the asset value, net profit (loss), cost of goods sold, average inventory and sales value for the year. Second, the firm must report research and development expense during the period of 2005- 
2017. Third, the firm must have complete data needed for this study. Table 1 shows the sampling process resulting in 173 observations for further analysis.

Table 1: Sampling Process

\begin{tabular}{llc}
\hline No. & Criteria & Number of Firms 2005-2017 \\
\hline 1. & Number of financial statements of manufacturing firms listed on the IDX & 1,407 \\
2. & for the period of 2005-2017 & 1,165 \\
3. & Number of financial statements which do not report R\&D Expense & 36 \\
4. & Number of financial statements which cannot be accessed & 33 \\
& Total Observable Samples & 173 \\
\hline
\end{tabular}

\section{Measurement of Financial Performance}

Financial performance in this study is defined as the profitability that refers to the condition of the bottom line of a profit-oriented firm in a certain period. Financial performance is represented by the profitability performance measured by the return on asset (ROA). Therefore, the magnitude of ROA is measured using the following formula:

$$
F P=\frac{\text { Earning before extraordinary items }}{\text { Total asset }}
$$

\section{Measurement of Innovation}

Innovation in this study is defined as the firms' efforts to discover ideas for continuous improvements, new and/or different methods and technologies, cost reduction as well as any development to meet customer needs. Innovation is measured using a proxy of research and development expense and calculated using the following formula.

$$
\text { INNOVATION }=\frac{\text { R\&D Expense }}{\text { Average total asset }}
$$

\section{Measurement of Process Capital}

Process capital in this study is defined as the efficiency of the manufacturing process. The cost of goods sold growth was employed as a proxy for measuring process efficiency. Cost of goods sold consists of direct material, direct labor and factory overhead costs. When a firm can efficiently manage its resources during manufacturing processes, the cost of goods sold decreases and it can generate more gross profit. A firm that performs well is a firm that manages its production process by reducing production time and inputs as well as improving product quality. Process capital is measured by a proxy of the growth of the cost of goods sold using the following formula.

$$
\text { PROCESS }=\frac{\operatorname{COGS}(\mathrm{t})-\operatorname{COGS}(\mathrm{t}-1)}{\operatorname{COGS}(\mathrm{t}-1)}
$$

\section{Measurement of Marketing Performance}

Marketing performance in this study is defined as the result of the overall marketing activities measured by sales. Marketing performance is measured using the following formula.

$$
M P=\log S A L E S
$$

\section{Control Variables}

This study also employs four control variables that are commonly used in the previous research, namely: firm size, leverage, the board of commissioners, and board of directors. Firm size is measured by the logarithm of the total asset. Leverage is measured by the ratio of debt to the total asset. Board of commissioner refers to the number of commissioners. Board of directors also refers to the number of directors.

\section{Analysis Method}

To test the hypotheses of the study, the partial least squares structural equation modeling (PLS-SEM) was employed for the following reasons: First, it simultaneously enables to solve multiple dependent and independent variables. Second, it is suitable for handling small sample size. Third, it does not demand a normal distributional assumption (Chin, 1998a, 1998b). 


\section{RESEARCH RESULTS}

\section{Descriptive Statistics}

Table 2 provides descriptive statistics of all variables included in this study. Results of descriptive statistics reveal the following findings. First, financial performance (ROA) of the sample firms is relatively homogeneous (mean: 0.009 and standard deviation: 0.010). This indicates that most sample firms have similar capabilities in profitability. Second, innovation in sample companies is heterogeneous (mean: 0.003 and standard deviation: 0.004). This indicates sample firms might have different policies in terms of creating value through innovations and spending R\&D expense compared to their assets. Third, the process capital (PROCESS) of the sample firms is relatively homogeneous (mean: 0.328 and standard deviation: 3.788). This shows that most sample firms have relatively similar capabilities in managing the manufacturing process. Fourth, marketing performance of the sample firms is relatively heterogeneous (mean: 9,693,000,000,000; standard deviation: $15,610,000,000,000$ ). This reveals that most sample firms vary in achieving sales growth.

Table 2: Descriptive Statistics

\begin{tabular}{lrrrrr}
\hline & Mean & Median & Minimum & Maximum & Standard Deviation \\
\hline FP & 0.009 & 0.007 & -0.015 & 0.042 & 0.021 \\
INNOVATION & 0.003 & 0.001 & 0.000 & 49.551 & 0.004 \\
PROCESS & 0.328 & 0.000 & -0.007 & 3.788 \\
SALES & $9,693,000,000,000$ & $3,769,000,000,000$ & $310,700,000,000$ & $89,070,000,000,000$ & $15,610,000,000,000$ \\
TASSET & $8,598,000,000,000$ & $4,219,000,000,000$ & $305,800,000,000$ & $44,230,000,000,000$ & $10,630,000,000,000$ \\
LEVERAGE & 0.352 & 0.302 & 0.000 & 1.175 & 0.221 \\
BOC & 5.098 & 5.000 & 2.000 & 11.000 & 1.873 \\
BOD & 5.803 & 5.000 & 3.000 & 16.000 & 2.337 \\
Note: FP or financial performance is earning before extraordinary items divided by total asset (ROA); INNOVATION is R\&D expense divided by \\
total asset; PROCESS is COGS growth; SALES is total sales in a year; TASSET is total asset in a year; LEVERAGE is total liabilities divided by \\
total asset BOC is the total number of commissioners; BOD is the total number of directors \\
\hline
\end{tabular}

\section{Pearson Correlation}

Table 3 provides the result of Pearson correlation test, which is conducted to determine the linear relationship between two random variables (Zhou et al., 2016). Innovation and process have no significant correlation to the financial performance. Market performance and other control variables are significantly correlated with financial performance.

Table 3: Pearson Correlation

\begin{tabular}{|c|c|c|c|c|c|c|c|c|}
\hline & [1] & [2] & [3] & [4] & [5] & [6] & [7] & [8] \\
\hline [1] FP & 1.000 & & & & & & & \\
\hline \multirow{2}{*}{ [2] INNOVATION } & 0.051 & 1.000 & & & & & & \\
\hline & $(0.506)$ & & & & & & & \\
\hline \multirow{2}{*}{ [3] PROCESS } & -0.079 & -0.060 & 1.000 & & & & & \\
\hline & $(0.299)$ & $(0.437)$ & & & & & & \\
\hline \multirow{2}{*}{ [4] MP } & $0.446^{* * *}$ & 0.121 & $-0.141^{*}$ & 1.000 & & & & \\
\hline & $(0.000)$ & $(0.111)$ & $(0.065)$ & & & & & \\
\hline \multirow{2}{*}{ [5] FSIZE } & $0.360^{* * *}$ & 0.008 & 0.045 & $0.926^{* * *}$ & 1.000 & & & \\
\hline & $(0.000)$ & $(0.921)$ & $(0.553)$ & $(0.000)$ & & & & \\
\hline \multirow{2}{*}{ [6] LEVERAGE } & $-0.440^{* * *}$ & -0.091 & $-0.132^{*}$ & -0.054 & $-0.174^{* *}$ & 1.000 & & \\
\hline & $(0.000)$ & $(0.235)$ & $(0.083)$ & $(0.478)$ & $(0.022)$ & & & \\
\hline \multirow{2}{*}{ [7] $\mathrm{BOC}$} & $0.317^{* * * *}$ & 0.093 & -0.056 & $0.451^{* * *}$ & $0.503^{* * * *}$ & $-0.205^{* * *}$ & 1.000 & \\
\hline & $(0.000)$ & $(0.226)$ & $(0.465)$ & $(0.000)$ & $(0.000)$ & $(0.007)$ & & \\
\hline \multirow{2}{*}{ [8] BOD } & $0.332^{* * *}$ & -0.056 & -0.026 & $0.352^{* * *}$ & $0.367^{* * *}$ & $-0.348^{* * *}$ & $0.464^{* * *}$ & 1.000 \\
\hline & $(0.000)$ & $(0.461)$ & $(0.733)$ & $(0.000)$ & $(0.000)$ & $(0.000)$ & $(0.000)$ & \\
\hline
\end{tabular}




\section{[1]}

[2]

[3]

[4]

[5]

[6]

[7]

[8]

Note: FP or financial performance is earnings before extraordinary items divided by total asset (ROA); INNOVATION is R\&D expense divided by total asset; PROCESS is COGS growth; SALES is total sales in a year; TASSET is total asset in a year; LEVERAGE is total liabilities divided by total asset; BOC is the total number of commissioners; BOD is the total number of directors

\section{Structural Model Analysis}

We use the structural model analysis to test the hypothesized relationships, particularly to investigate: (1) whether the effect of innovation on financial performance is direct or mediated by marketing performance, and (2) whether the effect of process capital on financial performance is direct or mediated by marketing performance. A stepped approach is used in the functioning of structural model analysis (Baron \& Kenny, 1986; Luft \& Shields, 2003; Hartmann \& Slapnicar, 2009).

\section{Direct Effects}

We ran the PLS to test whether innovation directly affects financial performance as stated in the first hypothesis (H1), and to test whether the process capital directly affects financial performance as stated in the second hypothesis (H2). As seen in Table 3 (Panel A), the results show that innovation (IN) is positively and significantly associated with financial performance (FP) ( $\beta$ Coefficient: $0.20 ; p<.01$ ). It can be concluded that the first hypothesis $(\mathrm{H} 1)$ is supported. Process capital (PC) is also significantly associated with financial performance (FP) ( $\beta$ Coefficient: $-0.10 ; p=0.08$. This also suggests that the second hypothesis (H2) is also supported.

Second, marketing performance (MP) was introduced as the mediating variable to test the other hypotheses. By inserting marketing performance (MP) as the mediating variable, the results reveal that: (1) innovation (IN) is positively associated with marketing performance (MP) ( $\beta$ Coefficient: $0.25 ; \mathrm{p}<0.01$ ). This shows that the third hypothesis (H3) is supported; (2) process capital (PC) is associated with marketing performance (MP) with a negative sign ( $\beta$ Coefficient: $0.20 ; p<0.01)$. This suggests that the fourth hypothesis (H4) is supported. (3) Marketing performance is associated with financial performance ( $\beta$ Coefficient: 0.61; $p<0.01$ ). This means that the fifth hypothesis (H5) is supported.

\section{Indirect Effects}

As seen in Table 4 Panel B, the association between innovation (IN) and financial performance (FP) after the insertion of marketing performance (MP) remains significant ( $\beta$ Coefficient: $0.12 ; \mathrm{p}=0.06$ ). This result suggests that marketing performance (MP) partially mediates the relationship between innovation (IN) and financial performance (FP) meaning that marketing performance (MP) still has a direct effect on financial performance (FP) while there is an indirect effect of marketing performance (MP) on financial performance (FP) via marketing performance (MP). Further analysis also shows that after introducing marketing performance (MP) as the mediating variable, the direct relationship between process capital (PC) and financial performance (FP) becomes insignificant. This demonstrates that marketing performance (MP) fully mediates the relationship between process capital (PC) and financial performance (FP).

Table 4: Summary of the structural model analysis

\begin{tabular}{|c|c|c|c|}
\hline PANEL A: & $\beta$ Coefficient & P-value & Decision \\
\hline \multicolumn{4}{|c|}{ Before including MP as the mediating variable } \\
\hline \multicolumn{4}{|l|}{ Direct Effect } \\
\hline $\mathrm{IN}>\mathrm{FP}$ & 0.20 & $<0.01$ & Significant $* * *, \mathrm{H}_{1}$ is supported \\
\hline $\mathrm{PC}>\mathrm{FP}$ & -0.10 & 0.08 & Significant*, $\mathrm{H}_{2}$ is supported \\
\hline PANEL B: & $\beta$ Coefficient & P-value & Description \\
\hline \multicolumn{4}{|c|}{ After including MP as the mediating variable } \\
\hline \multicolumn{4}{|l|}{ Direct Effect } \\
\hline IN $>$ FP & -0.12 & 0.06 & Significant $* *$ \\
\hline $\mathrm{PC}>\mathrm{FP}$ & 0.03 & 0.35 & Not significant \\
\hline $\mathrm{IN}>\mathrm{MP}$ & 0.25 & $<0.01$ & Significant $* * *, \mathrm{H}_{3}$ is supported \\
\hline $\mathrm{PC}>\mathrm{MP}$ & -0.20 & $<0.01$ & Significant $* * *, \mathrm{H}_{4}$ is supported \\
\hline $\mathrm{MP}>\mathrm{FP}$ & 0.61 & $<0.01$ & Significant $* * *, \mathrm{H}_{5}$ is supported \\
\hline PANEL C: & $\beta$ Coefficient & & Decision \\
\hline \multicolumn{4}{|l|}{ Indirect Effects } \\
\hline $\mathrm{IN}>\mathrm{MP}>\mathrm{FP}$ & $0.25 \times 0.61=0.15$ & & $\mathrm{H}_{6}$ is supported, partial mediation \\
\hline $\mathrm{PC}>\mathrm{MP}>\mathrm{FP}$ & $-0.20 \times 0.61=-0.12$ & & $\mathrm{H}_{7}$ is supported, full mediation \\
\hline Note: 1$)^{* * * \text { Signi }}$ & gnificant at $\mathrm{p}<0.05 ; * \mathrm{Si}$ & nt at $p$ & \\
\hline
\end{tabular}




\section{Control Variables}

This study employs four control variables, namely firm size $(\beta$ Coefficient $=0.35 ; p<0.01)$, leverage $(\beta$ Coefficient $=-$ $0.43) ; \mathrm{p}<0.01$, the board of commissioners $(\beta$ Coefficient $=-0.05 ; \mathrm{p}<0.25)$ and board of directors ( $\beta$ Coefficient: 0.16 ; $\mathrm{p}<0.01)$. The structural model analysis shows that firm size, leverage, and board of directors significantly affect financial performance. Only the board of commissioners does not significantly affect financial performance.

\section{DISCUSSION / ANALYSIS}

Before introducing marketing performance as the mediating variable, it is empirically proven that innovation has a positive direct effect on financial performance. This provides additional support for many previous studies, such as Cefis and Ciccarelli (2005), Padgett (2012), Aguilera-Caracuel and Ortiz-de-Mandojana (2013), and Bigliardi (2013). This means that some manufacturing firms in Indonesia have invested in $R \& D$ and the innovations have improved their financial performance.

After the introduction of marketing performance as the mediating variable, it is empirically confirmed that marketing performance partially mediates the relationship between innovation and financial performance. The direct effect of innovation to financial performance has a negative sign. This finding suggests that some innovations do not directly affect financial performance. Some innovations still take a longer time to get market acceptance. Some process innovations might fail during the implementation, and some innovations might fail in the market. Those failures cause losses for some manufacturing firms.

This study provides empirical evidence that innovation is positively associated with marketing performance. This also provides additional support for previous studies, such as Al-Zyadaat and Al-Awamreh (2012) and Lagat and Frankwick (2017). This shows that marketing activities of the publicly listed manufacturing firms in Indonesia have benefited from the innovations, and therefore they can improve marketing performance. Such innovations might be in the form of product innovations or marketing innovations. Further analysis reveals that marketing performance is positively associated with financial performance. This finding supports the previous studies of Feng et al. (2015), Lagat and Frankwick (2017), and Shi et al. (2018). In conclusion, this study demonstrates that marketing performance mediates innovation-financial performance relationship. This result has practical implications for managers of listed manufacturing firms. They need to keep innovating in product or process innovations in order to improve marketing performance because it will enhance the profitability of firms.

Before introducing marketing performance as the mediating variable, this study also provides empirical evidence that process capital is associated with financial performance. Different from the previous studies that use human capital productivity as the proxy, process capital in this study refers to the cost of goods sold growth performance. The negative sign on the relationship between process capital and financial performance means that the increasing growth of the cost of sold goods will decrease profitability performance, and vice versa, the decreasing cost of sold goods will increase profitability and performance of firms.

By introducing marketing performance as the mediating variable, it is empirically proven that marketing performance fully mediates the relationship between process capital and financial performance. This negative sign in process capitalmarketing performance relationship suggests that the increase in the cost of goods sold will cause the disadvantages in marketing activities. The increasing costs will also decrease the competitive advantage of publicly listed manufacturing firms in Indonesia. This result has practical implications for managers. They need to keep improving manufacturing processes to produce cost efficiencies in order to enhance marketing performance so that it will increase the profitability performance of firms.

\section{CONCLUSION, IMPLICATION, AND LIMITATION}

This research aims to investigate the mediating role of marketing performance on innovation-financial performance relationship as well as on process capital-financial performance relationship using the publicly listed manufacturing firms on the Indonesia Stock Exchange (IDX). As quantitative research employing marketing performance as the mediation variable, a mediation research model is constructed to test the hypotheses studied. Return on assets as the measure profitability is employed as the proxy of financial performance. A new data set is prepared which involves the publicly listed manufacturing companies on the Indonesia Stock Exchange (IDX) covering the period of thirteen years from 2005 to 2017. This research provides empirical evidence as to the following. Firstly, marketing performance partially mediates 
the relationship between innovation and financial performance. Secondly, marketing performance fully mediates the relationship between process capital and financial performance.

When many previous studies investigate the direct relationship of the three determinants of financial performance, namely innovation, process capital, and marketing performance, this study focuses on the mediating role of marketing performance. Therefore, this study provides a better understanding for managers regarding the mechanism of how innovation affects financial performance via marketing performance as well as on the mechanism of how to process capital affects financial performance via marketing performance. This study implies that managers need to continuously improve marketing management and continue to innovate and improve the manufacturing process. This study contributes to the theoretical development in term of providing empirical evidence to the literature of innovation management, process management, marketing management as well as finance and accounting.

The results of this study imply that managers of the publicly listed manufacturing firms in Indonesia must be aware of their capabilities in managing innovation and manufacturing process to improve marketing performance. Managers must also be aware that marketing performance mediates the innovation-financial performance as well as process capitalfinancial performance relationship.

The result of this study has an important implication to society in term of providing a comprehensive understanding and information on how the mechanism of a firm to achieve good financial performance in the capital market. This research model provides a framework for society to decide their investments.

This study has the following limitations. First, it covers only the publicly listed manufacturing companies in Indonesia. It leads to the limitation of generalization of the results. Therefore, future studies should cover a wider sample of industries for a better generalization to validate the same model. Second, this study employs secondary data derived from financial statements as proxies of variables. Future studies could use a survey method to get primary data in order to assess the insight of managers' perception. Third, this study employs the partial least squares structural equation modeling (PLSSEM) to test the causality among variables. This might lead to a debatable issue on the more proper method to test the cause-effect relationship. It is suggested that future studies employ other methods, such as experiment method to test the causality. Third, this study employs only three determinants of financial performance, namely innovation, process capital, and marketing performance. Future studies might add other variables to build a more comprehensive research model, such as the role of competitive strategy and performance management.

\section{ACKNOWLEDGEMENT}

This research is supported by Universitas Airlangga and the authors are immensely grateful for the help.

\section{REFERENCES}

Aguilera-Caracuel, J., \& Ortiz-de-Mandojana, N. (2013), Green Innovation and Financial Performance: An Institutional Approach. Organization and Environment, https://doi.org/10.1177/1086026613507931

Al-Zyadaat, M.A., Saudi, M.A., \& Al-Awamreh, M.A. (2012). The Relationship Between Innovation and Marketing Performance in Business Organizations: An Empirical Study on Industrial Organizations in the Industrial City of King Abdullah II. International Business and Management, http://dx.doi.org/10.3968/j.ibm.1923842820120502.1135।

Atalay, M., Anafarta, N., \& Sarvan, F. (2013). The relationship between innovation and firm performance: An empirical evidence from Turkish automotive supplier industry. Procedia-Social and Behavioral Sciences, https://doi.org/10.1016/j.sbspro.2013.04.026

Baron, R.M., \& Kenny, D. (1986). The Moderator-Mediator Variable Distinction in Social Psychological Research: Conceptual, Strategic, and Statistical Consideration. Journal of Personality and Social Psychology, https://doi.org/10.1037/0022-3514.51.6.1173

Bigliardi, B. (2013). The Effect of Innovation on Financial Performance: A Research Study Involving SMEs. Innovation: Management, Policy and Practice, 14(2), 245-255.https://doi.org/10.5172/impp.2013.15.2.245

Cefis, E., \& Ciccarelli, M. (2005). Profit differentials and innovation. Economics of Innovation and New Technology, 14(1-2), 43-61.https://doi.org/10.1080/1043859042000232160

Cefis, E., \& Marsili, O. (2004). A Matter of Life and Death: Innovation and Firm Survival.Industrial and Corporate Change, https://doi.org/10.1093/icc/dth081 
Chaston, I., \& Scott, G.J. (2012). Entrepreneurship and open innovation in an emerging economy. Management Decision, https://doi.org/10.1108/00251741211246941

Chen, J., Zhaoui, Z., \& Hon, Y.X. (2004). Measuring Intellectual Capital: A New Model and Empirical Study. Intellectual Capital, https://doi.org/10.1108/14691930410513003

Cheng, M.Y., Lin, J.Y., Hsiao, T.H., \& Lin, W.T. (2010). Invested resource, competitive intellectual capital, and corporate performance. Intellectual Capital, https://doi.org/10.1108/14691931011085623

Chin, W.W (1998b). The Partial Least Squares Approach to Structural Equation Modelling. In G. A. Marcoulides (Eds.), Modern methods for business research. London: Lawrence Erlbaum Associates.

Chin, W.W. (1998a). Issues and opinion on SEM. MIS Quarterly, 51, 1173-1182.

Chiu, C.L., \& Chen, Y.S. (2017). A web-scale experience to identify the component impacts of intellectual capital on corporate performance from the perspective of multimedia data applications. International Journal of Applied Systemic Studies, https://doi.org/10.1504/IJASS.2017.088907

Darroch, J. (2005). Knowledge management, innovation, and firm performance. Knowledge Management, https://doi.org/10.1108/13673270510602809

Ernst, H., Hoyer, W.D., Krafft, M. \& Krieger, K. (2010). Customer relationship management and company performance: the mediating role of new product performance. Journal of the Academy of Marketing Science, https://doi.org/10.1007/s11747-010-0194-5

Ezzi, F., \& Jarboui, A. (2016). Does innovation strategy affect financial, social and environmental performance?. Journal of Economics, Finance and Administrative Science, https://doi.org/10.1016/j.jefas.2016.03.001

Fagerberg, J., Mowery, D.C., \& Nelson, R.R. (2004). The Oxford Handbook of Innovation, USA: Oxford University Press.

Feng, H., Morgan, N.A., \& Rego, L.L. (2015). Marketing Department Power and Firm Performance. Journal of Marketing, https://doi.org/10.1509/jm.13.0522

Ferrari, M., \& La Rocca, L. (2010). Innovation and Performance: Some Evidence From Italian Firms. In M.J. Epstein, JF. Manzoni, \& A.Davila (Eds.), Studies in Managerial and Financial Accounting, Volume 20: Performance Measurement and Management Control: Innovative Concepts and Practices (115 - 141). Emerald Group Publishing Limited.

Freeman, R.E. (1984). Stakeholder management: A stakeholder approach. Marshfield, MA: Pitman Publishing.

Gartenberg, C., Prat, A. \& Serafeim, G. (2019). Corporate Purpose and Financial Performance. Organization Science, https://doi.org/10.1287/orsc.2018.1230

Gunday, G., Ulusoy, G., Kilic, K., \& Alpkan, L. (2011). Effects of Innovation Types on firm Performance. International Journal of Production Economics, https://doi.org/10.1016/j.ijpe.2011.05.014

Hariyati \& Tjahjadi, B. (2018). Contingent Factors Affecting the Financial Performance of Manufacturing Companies: The Case of East Java, Indonesia. Asian Journal of Business and Accounting, https://doi.org/10.22452/ajba.vol11no1.5

Hartmann, F., \& Slapnicar, S. (2009). How formal performance evaluation affects trust between superior and subordinate managers. Accounting, Organizations and Society, https://doi.org/10.1016/j.aos.2008.11.004

Jansson, C. (2018). Financial Resilience: The Role of Financial Balance, Profitability, and Ownership. In: S. Tengblad \& M. Oudhuis (Eds.), The Resilience Framework. Work, Organization, and Employment. Singapore: Springer.

Kalkan, A., Bozkurt, Ö.Ç., \& Arman, M. (2014). The Impacts of Intellectual Capital, Innovation and Organizational Strategy on Firm Performance. Procedia - Social and Behavioral Sciences, https://doi.org/10.1016/j.sbspro.2014.09.025

Kaplan, R.S., \& Norton, D.P. (2001). Transforming the Balanced Scorecard from Performance Measurement to Strategic Management: Part II. Accounting Horizons, https://doi.org/10.2308/acch.2001.15.2.147

Keats, B.W., \& Hitt, M.A. (1998). A Causal Model of Linkages Among Environmental Dimensions, Macro Organizational Characteristic and Performance. Academy of Management Journal, https://doi.org/10.2307/256460 
Khan, F. R., Hatami, Y. J., Sasidharan, A., \& Al-Roshdi, S. A. A. (2017). Investigative Study of Preferred Social Media Marketing in Safeer Mall, Sohar, Oman. Humanities \& Social Sciences Reviews, https://doi.org/10.18510/hssr.2017.515

Kianto, A., Sáenz, J., \& Aramburu, N. (2017). Knowledge-based human resource management practices, intellectual capital, and innovation. Journal of Business Research, https://doi.org/10.2478/orga-2019-0002

Lagat, C., \& Frankwick, G.L. (2017). Marketing capability, marketing strategy implementation and performance in small firms. Journal for Global Business Advancement, https://doi.org/10.1504/JGBA.2017.10005516

Liu, L., Qu, W., \& Haman, J. (2018). Product market competition, state-ownership, corporate governance, and firm performance. Asian Review of Accounting, https://doi.org/10.1108/ARA-05-2017-0080

Luft, J., \& Shields, M.D. (2003). Mapping management accounting: graphic and guidelines for theory-consistent empirical research. Accounting, Organization and Society, https://doi.org/10.1016/S0361-3682(02)00026-0

Mahmoud, M.A., Blankson, C., Owusu-Frimpong, N., Nwankwo, S., \& Trang, T.P. (2016). Market Orientation, Learning Orientation, and Business Performance: The Mediating Role of Innovation. International Journal of Bank Marketing, https://doi.org/10.1108/IJBM-04-2015-0057

Narver, J.C., \& Slater, S.F. (1990). The Effect of a Market Orientation on Business Profitability. Journal of Marketing, https://doi.org/0.2307/1251757

OECD (2005). Oslo Manual: Guidelines for Collecting and Interpreting Innovation Data. Paris: OECD Publishing and Eurostat.

Padgett, R.C., \& Moura-Leite, R.C. (2012). Innovation with High Social Benefits and Corporate Financial Performance. Journal of Technology,Management Innovation, http://dx.doi.org/10.4067/S0718-27242012000400005

Prajogo, D., Oke, A., \& Olhager, J. (2016). Supply Chain Processes: Linking Supply Logistics Integration, Supply Performance, Lean Processes, and Competitive Performance. International Journal of Operations \& Production Management, https://doi.org/10.1108/JJOPM-03-2014-0129

Rajapathirana, R.J., \& Hui, Y. (2018). Relationship between innovation capability, innovation type, and firm. Journal of Innovation and Knowledge, https://doi.org/10.1016/j.jik.2017.06.002

Rashid Al-Thehli, F. A., \& Ahamat, A. (2019). Managing Innovation and Creativity In Human Resource Management: A Critical Review Of Literature. Humanities \& Social Sciences Reviews, https://doi.org/10.18510/hssr.2019.723

Schramm-Klein, H., \& Morschett, D. (2006). The Relationship between marketing performance, logistics performance and company performance for retail companies. The International Review of Retail, Distribution and Consumer Research, https://doi.org/10.1080/09593960600572399

Shi, Y., Lim, J.M., Weitz, B.A., \& France, S.L. (2018). The impact of retail format diversification on retailers' financial performance. Journal of the Academy of Marketing Science, https://doi.org/10.1007/s11747-017-0559-0

Shukla, S. (2017). Innovation and Economic Growth: A Case Of India. Humanities \& Social Sciences Reviews, https://doi.org/10.18510/hssr.2017.521

Slater, S.F., \& Olson, E M. (2001). Marketing's Contribution to the Implementation of Business Strategy: An Empirical Analysis. Strategic Management Journal, https://doi.org/10.1002/smj.198

Smith, M., \& Chang, C. (2010). Improving customer outcomes through the implementation of customer relationship management. Asian Review of Accounting, https://doi.org/10.1108/13217341011089658

Tuan, N., Nhan, N., Giang, P., \& Ngoc, N. (2013). The Effects of Innovation on Firm Performance of Supporting Industries in Hanoi - Vietnam. Journal of Industrial Engineering and Management, http://dx.doi.org/10.3926/jiem.1564

Wang, W.Y., \& Chang, C. (2005). Intellectual capital and performance in causal models: Evidence from the information technology industry in Taiwan. Intellectual Capital, https://doi.org/10.1108/14691930510592816

Wulan Sari, D. (2019). Ratio Analysis of Financial Performance Of Companies Q45 Index Listed. Humanities \& Social Sciences Reviews, https://doi.org/10.18510/hssr.2019.7361 
Yaakub, M.B. \& Othman, K. (2014). The Foundation of Knowledge Management: A Review from Conventional and Islamic Perspectives. Humanities and Social Sciences Review, CD-ROM. ISSN: 2165-6258 :: 03(03):65-77

Yu, W., Ramanathan, R., \& Nath, P. (2013). The impacts of marketing and operations capabilities on financial performance in the UK retail sector: A resource-based perspective. Industrial Marketing Management, https://doi.org/10.1016/j.indmarman.2013.07.014

Zhou, H., Zhihong, D., Xia, Y., \& Fu, M. (2016). A new sampling method in particle filter based on the Pearson correlation coefficient. Neurocomputing, https://doi.org/10.1016/j.neucom.2016.07.036 